\title{
Using EVA As A \\ Decision Metric In Capital Budgeting
}

Christine McClatchey, (E-mail: christine.mcclatchey@unco.edu), University of Northern Colorado John Clinebell, (E-mail: john.clinebell@unco.edu), University of Northern Colorado

\begin{abstract}
Economic Value Added (EVA) has been growing in popularity within the business community as a measure of both value and performance. Despite this growth, EVA has yet to receive significant attention in the academic literature, particularly in micro decision-making areas such as capital budgeting. This paper examines the efficacy of EVA as a capital budgeting decision-making aid. Although a theoretical link between EVA and net present value (NPV) has been noted, issues related to its implementation have yet to be addressed. Our analysis details conditions under which EVA produces managerial decisions similar to those obtained by the NPV rule. Contrary to some claims, we find EVA and NPV produce different accept/reject decisions in a variety of commonly encountered capital budgeting situations.
\end{abstract}

\section{Introduction}

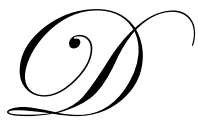

eveloped by Joel M. Stern and G. Bennett Stewart III of Stern Stewart \& Co., Economic Value Added (EVA) has been used as a decision-making aid and as a measure of corporate performance by many firms including corporate giants Cola-Cola, Eli Lilly, Quaker Oats, DuPont, and AT\&T. Briggs and Stratton boast a four-fold increase in their stock price during the four years following EVA implementation (Brigham, Gapenski and Daves, 1999); Coca-Cola notes a 200\% increase during the six years following its adoption of EVA (Chen and Dodd, 1997). EVA has received increasing attention in the general press and appears to be growing in popularity with the business community. In some respects EVA has become a panacea expected to cure a multiple of ills.

The superiority of EVA presumably stems from the fact that traditional accounting measures of performance, such as return on assets, return on equity and return on sales, ignore the cost of capital investments required to generate earnings. Stewart (1994, pg. 74) explains that "(EVA) charges management for using capital at an appropriate risk-adjusted rate and it eliminates financial and accounting distortions to the extent it is practical to do so." Its use, however, does not stop here. EVA has also been recommended as:

- a measure of divisional or business unit financial performance (when stock price measures are unavailable);

- $\quad$ the basis for an incentive-based compensation system;

- $\quad$ a tool to increase emphasis on the long-term importance and benefits of $R \& D$ and employee training;

- a tool for goal setting and financial planning;

- a capital budgeting decision criteria;

- a tool for shareholder communication.

Even with the growing support, many questions remain unanswered about the efficacy of EVA as a decision-making tool. Dillon and Owers (1997), Kramer and Pushner (1997), and Chen and Dodd (1997) note a general absence of academic research regarding EVA, despite its popularity in practitioner-orientated literature and in the general press. What literature does exist can be grouped into four broad categories. The first, mainly descriptive in nature, examines what EVA is, how it is computed, and how it is being used (Stern, Stewart and Chew, 1995; Barfield, 1998; Stewart, 1994; Wallace, 1997; Burkette and Hedley, 1997; de Villiers, 1997). Young (1999) provides a more detailed examination of the numerous non-GAAP adjustments to traditional accounting 
statements. Weaver (2001) surveys current EVA users and finds significant discrepancies in their approaches to computing all of the EVA inputs. Abdeen and Haight (2002) discuss the uses, benefits and limitations of EVA as a value creation measure. A comparison of Fortune 500 companies using EVA to those employing other performance metrics yields mixed results with regard to levels and changes in firm performance over time. Others have examined the relationship between EVA and managerial decision-making (Dillon and Owers, 1997; Rogerson, 1997; Lehn and Makhija, 1997).

The second category of academic research focuses on the relationship between EVA and accounting measures of performance, market value, stock price, and/or shareholder returns. Biddle, Bowen and Wallace (1997) find EVA does not dominate earnings in its association with stock market returns. Olsen (1996) finds EVA explains less than $2 \%$ of the variation in 1-year shareholder returns. Peterson and Peterson (1996) conclude EVA and EVA return-on-capital are poorly correlated with 1-year shareholder returns. Clinton and Chen (1998) find that, compared to other traditional performance measures, EVA is the only measure that does not exhibit a consistent association with stock returns. In contrast, O'Byrne (1997) finds that EVA dominates earnings in its ability to explain the variation in market value among companies and that changes in EVA and changes in capital explain significantly more of the variation in market value than changes in earnings. O'Byrne attributes various methodological differences for the differential results.

Lehn and Makhija (1996) follow 241 firms over a 7-year period and find that the correlation of EVA with stock returns is greater than with other measures (including various accounting rates of return) affording EVA a slight edge as a performance measure. Chen and Dodd (1997) find that improvements in EVA performance are related to higher stock returns although the relationship is not as strong as suggested by some anecdotal evidence. They also find that EVA explains more of the variation in stock returns than traditional measures of accounting profits, however, accounting earnings do provide significant incremental information suggesting EVA should not replace accounting variables as measures of corporate performance. A subsequent study by the same authors employing a different methodology and sample concludes that even though EVA is significantly associated with annual stock returns, it demonstrated very low explanatory power - lower than either residual income or operating income (Dodd and Chen, 1997).

The third area of research focuses on the association of EVA and market value added (MVA). Kramer and Pushner (1997) conclude that while the market seems more focused on profit than EVA, their mixed results are inconclusive. Grant (1996), however, does find that EVA significantly impacts the market value added of a firm. Variations in the EVA-to-capital ratios in his sample accounted for 32\% of the changes in MVA-to-capital ratios. Stewart (1991) and Stern, Stewart, and Chew (1995), the developers of EVA, have also provided support for the ability of EVA to proxy for MVA. Despite conflicting evidence many firms continue to adopt EVA as decisionmaking metric (Ryan and Trahan, 1999).

In contrast to prior research that has examined the use of EVA within its broadest context (as an overall firm valuation tool), we examine the more narrow application of EVA to the capital budgeting decision. Proponents of EVA such as Ehrbar (1999) note that the link to MVA makes EVA an ideal tool for capital budgeting. Because the present value of future EVA is the same as a project's contribution to the firm's MVA, managers can forecast the future EVA of a project, plant, a product line, or customer relationship and relate it directly to its contribution to firm value. As suggested by Stewart (1991), "discounting a project's EVA automatically results in its net present value." Coca-Cola and Harnischfeger Industries Inc. both reported having successfully applied EVA to identify value-adding capital budgeting projects (Abdeen and Haight, 2002).

Contrary to these claims, Damodaran (undated) finds that NPV and EVA will yield equivalent results only when strict assumptions regarding the relationships between the project's initial investment, depreciation expense, and capital charges are satisfied. Dillon and Owers (1997) also provide a technical analysis of the relationship between a project's NPV and the present value of its expected future EVA and demonstrate that the techniques will not generally provide identical solutions. They note the equivalence between NPV and the present value of EVA warrants further investigation. 
The question remains whether or not EVA is a good decision metric for use in capital budgeting and what, if any, are its limitations. To this end, we analyze EVA as a decision metric for the investment decision. We provide evidence on the strengths and weaknesses of EVA as a decision-making tool in capital budgeting. Various capital budgeting scenarios are examined to identify if and when EVA and NPV produce conflicting decisions.

\section{Economic Value Added}

Economic Value Added is generally defined as the difference between the firm's operating profits and cost of capital. If after-tax earnings are greater than the cost of capital, then EVA is positive and firm value should increase. The concept of EVA is straightforward: “( $(\mathrm{t}) \mathrm{rue}$ profits don't begin until the cost of capital, like all other costs, has been covered (Ehrbar, 1999)."

EVA overcomes the flaw in conventional accounting of ignoring the capital charge by subtracting the annual cost of all the capital a firm uses. Essentially the capital charge allows the firm to convert a balance sheet item (equity) into an income statement expense that can be analyzed in much the same way other operating expenses are analyzed. EVA increases if 1) operating profits grow without tying up any new capital, 2) new capital is invested to earn more than the cost of capital, or 3) capital is diverted from projects earning insufficient returns. Overall, managers are forced to use inventory, accounts receivables, and plant and equipment more effectively when attention is directed toward the costs of funding those assets.

Following Dillon and Owers (1997), EVA can be expressed as:

$$
\begin{aligned}
& \text { EVA= NOPAT }-C C^{2} \\
& \text { where: NOPAT }=(R-O C E-D) *(1-T) \\
& =(R-O C E) *(1-T)+T D-D \\
& \qquad \begin{aligned}
\mathrm{CC} \quad & \text { Capital charge }=(\text { Capital employed }) * \mathrm{WACC}^{3} \\
\mathrm{R} & =\text { Revenues } \\
\mathrm{OCE} & =\text { Operating cash expenses, excluding depreciation \& interest } \\
\mathrm{T} & =\text { Marginal tax rate } \\
\mathrm{D} & =\text { Depreciation expense }
\end{aligned}
\end{aligned}
$$

Stewart (1991) defines NOPAT as profits derived from the company's operations after taxes but before financing costs and non-cash bookkeeping entries. Alternatively, it is the total pool of profits available to provide a cash return to all financial providers of capital to the firm. The only non-cash charge that is deducted from NOPAT is depreciation because it is considered a true economic expense. Capital is defined as the sum of all cash that has been invested in a company's net assets over its life and without regard to financing form, accounting name, or business purpose (Stewart, 1991, pp. 86). To be consistent with the deduction of depreciation from NOPAT, capital employed is charged with accumulated depreciation.

To apply the EVA concept to an N-year capital budgeting project, it is first necessary to define "capital employed." The capital charge is then computed as the firm's weighted average cost of capital times the amount of capital employed. ${ }^{4}$ The intent of EVA is to annually charge a project for its use of capital. Theoretically, capital employed would equal the economic value of a project's asset(s). In practice, however, EVA users would likely rely on financial statement data (book values) rather than trying to forecast the market value of all the project's assets in each period. Thus, capital employed (and hence EVA) will reflect the project's book rate of depreciation rather than its economic rate of depreciation, which are almost never the same (Lavin and Zorn, 2000). ${ }^{5}$ 


\section{The Relationship between EVA and NPV}

A project's annual after-tax operating cash flow can be given by:

$$
\begin{aligned}
& O C F=(R-O C E)-T^{*}(R-O C E-D) \\
& O C F=(R-O C E) *(1-T)+T D \\
& O C F=N O P A T+D
\end{aligned}
$$

Letting INV equal the project's initial investment, NPV can be given by:

$$
\begin{aligned}
& N P V=-I N V+\sum_{t=1}^{N} \frac{O C F_{t}}{(1+W A C C)^{t}} \\
& N P V=-I N V+\sum_{t=1}^{N} \frac{N O P A T_{t}+D_{t}}{(1+W A C C)^{t}}
\end{aligned}
$$

Recall a project's annual EVA is equal to NOPAT minus a capital charge. A project's overall EVA is equal to the present value of its periodic (or annual) EVAs and can be expressed as:

$$
\begin{aligned}
& E V A_{\text {Pr oject }}=\sum_{t=1}^{N} \frac{E V A_{t}}{(1+W A C C)^{t}} \\
& E V A_{\text {Pr oject }}=\sum_{t=1}^{N} \frac{N O P A T_{t}-C C_{t}}{(1+W A C C)^{t}}
\end{aligned}
$$

A comparison of (3b) and (4b) reveals that NPV will equal EVA if and only if:

$$
\begin{aligned}
& -I N V+\sum_{t=1}^{N} \frac{D_{t}}{(1+W A C C)^{t}}=\sum_{t=1}^{N} \frac{-C C_{t}}{(1+W A C C)^{t}} \\
& \sum_{t=1}^{N} \frac{D_{t}}{(1+W A C C)^{t}}+\sum_{t=1}^{N} \frac{C C_{t}}{(1+W A C C)^{t}}=I N V
\end{aligned}
$$

The intuition underlying (5b) is simple. NPV accounts for a project's capital investment entirely at its inception date (-INV at $\mathrm{t}=0$ ). EVA distributes this charge each year throughout the project's life by subtracting depreciation expense from NOPAT and by the annual deduction of a capital charge. Excluding INV as an up front cash outflow correctly prevents the EVA model from double counting the cost of capital invested. The problem with converting the capital investment to an annual charge is that book values, rather than true economic values, are generally used for computing capital employed for each subsequent time period. For the two decision metrics to produce identical results, they must account for the project's capital investment similarly. ${ }^{6}$ 


\section{NPV and EVA as Decision Metrics}

From the preceding section, it is apparent that NPV and EVA do not always give identical capital budgeting decisions rules. Furthermore, the capital charge is defined as capital employed multiplied by the firm's weighted average cost of capital and there are several alternatives for measuring the level of capital employed. The first, book value measures, can be defined as the asset's beginning-of-period book value or its end-of-period book value, in each year of the project. Alternatively Dillon and Owers (1997) suggest using "average operating assets," or AOA, defined as net investment divided by two.

The following scenarios compare NPV and EVA using different measures of capital employed. Standard treatment for depreciation is to assume the firm will employ the Modified Accelerated Cost Recovery System for tax purposes; thus, for both NPV and NOPAT computations, a MACRS depreciation schedule is employed. We examine three possible definitions of capital employed; for each we assume a project with an economic life exactly equal to its depreciable life. Comparisons are then made for projects with economic lives greater than and less than their depreciable lives. The hypothetical project under consideration assumes the following:

$\begin{array}{ll}\text { Initial investment } & \$ 400 \\ \text { Sales - expenses } & \$ 70 \\ \text { Salvage value } & \$ 0 \\ \text { Tax rate } & 20 \% \\ \text { Depreciation } & \text { MACRS 7-year property class } \\ \text { Economic life (3 scenarios) } & 8 \text { years; 10 years; 7 years } \\ \text { WACC } & 10 \%\end{array}$

Beginning-of-year book values for the capital charge

The results obtained when using the project's beginning-of-year book values for the capital charge are provided in Table 1. If the project under consideration has an economic life equal to its depreciable life, then the use of beginning-of-year book values for the capital charge will result in Equation (6) holding. ${ }^{7}$ That is, under these limiting circumstances, NPV and EVA will give identical solutions and can be considered equivalent capital budgeting techniques. This result is independent of the method of depreciation (MACRS or straight-line), as long as the asset is fully depreciated.

If the project's economic life extends beyond its depreciable life, the additional cash flows to EVA and NPV are identical. Both depreciation expense and the capital charge are zero for the additional years (those beyond the project's depreciable life). The change in NOPAT for each additional year affects NPV and EVA identically.

If the project's economic life is less than its depreciable life, then EVA and NPV will not yield identical solutions. Recall that for the same solution to exist, $-\mathrm{INV}+\mathrm{PV}(+\mathrm{D})=\mathrm{PV}(-\mathrm{CC})$. If the project's economic life is shortened, both NPV and EVA lose PV(NOPAT), so the marginal effect of this is zero. ${ }^{8}$ The change in PV $(+\mathrm{D})$, however, will not equal the change in PV(-CC); in fact the cash flows have opposite signs. The effect is negative on NPV (removing a positive cash flow) and positive on EVA (removing a negative cash flow). Overall, the values of both metrics fall by the decline in PV(NOPAT), but NPV falls more. In this case, NPV and EVA may yield conflicting capital budgeting decisions with EVA accepting projects that are rejected by NPV.

\section{End-of-year book values for the capital charge}

Table 2 illustrates the model's results when using end-of-year book values for the capital charge. In the case where the project's economic life is equal to its depreciable life, the use of the asset's end-of-year book value for the capital charge increases EVA relative to NPV. Specifically, an asset's end-of-year book value is less than its beginning-of-year book value, reducing EVA's capital charge each year. No other cash flows are affected. Overall EVA will be greater than NPV, thus EVA may incorrectly accept an unprofitable project (unprofitable in the sense that NPV would reject it). 
If a project's economic life is extended beyond its depreciable life, the additional cash flows added to the years beyond the depreciable life are identical for EVA and NPV. Both depreciation and the capital charge equal zero, and NOPAT increases by the same amount for EVA and NPV. Thus, similar to the previous example, EVA will always produce a higher statistic than NPV.

If a project's economic life is less than its depreciable life, it appears that the cash flows being eliminated are much greater for NPV than they are for EVA. Both NPV and EVA lose the additional NOPAT. However, under the NPV model the initial investment (-INV) does not change as the project's economic life is shortened but $\mathrm{PV}(+\mathrm{D})$ decreases resulting in a lower NPV. For EVA, capital charges are reduced causing EVA to decrease at a slower rate. Although the values of both metrics fall, the value of NPV decreases at a faster rate.

Table 1

Comparison of NPV and EVA using beginning-of-year book values for the capital charge Initial Outlay $=\$ 400$, Depreciation $=$ MACRS 7-year, WACC $=10 \%$

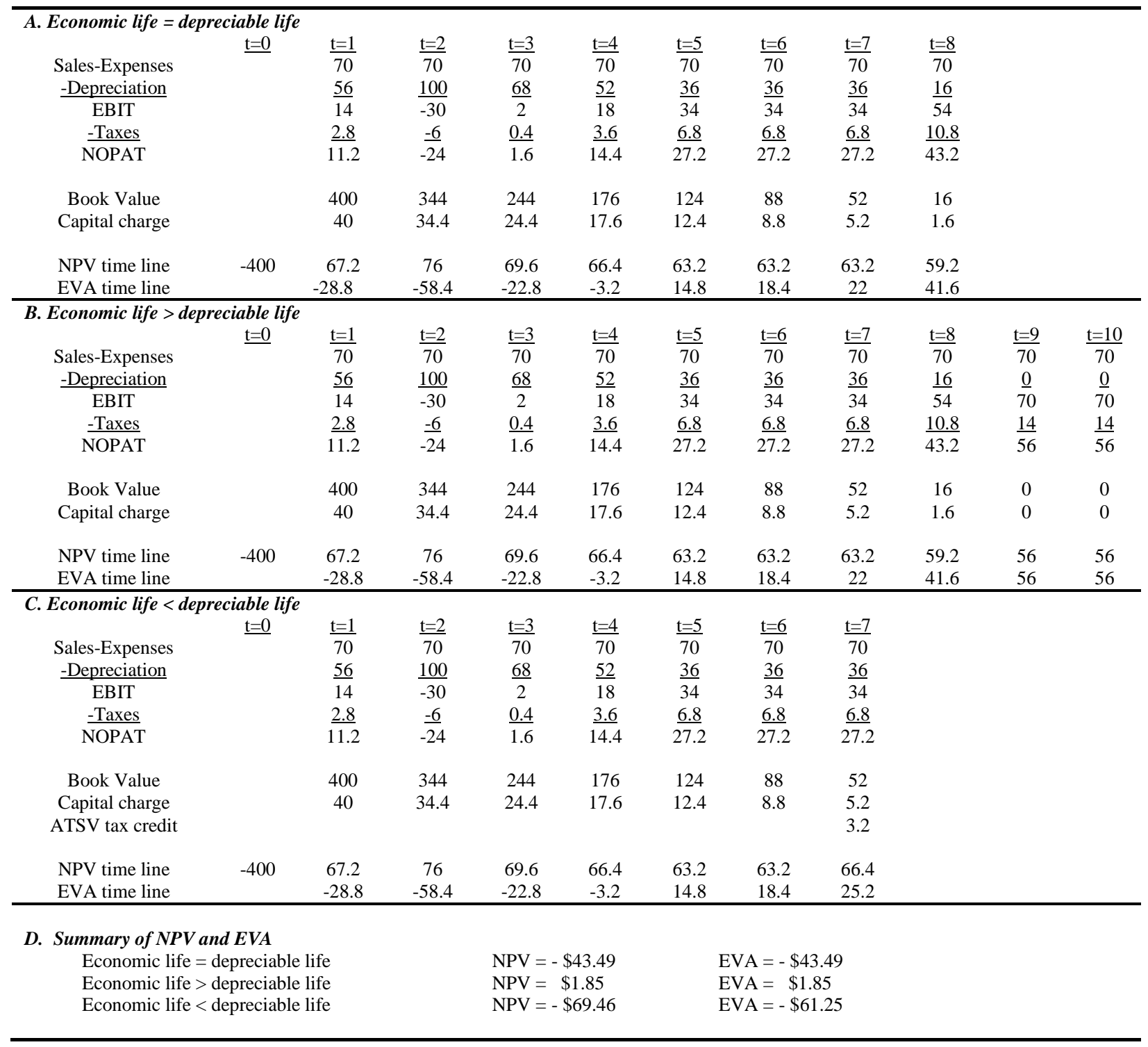


Table 2

Comparison of NPV and EVA using end-of-year book values for the capital charge Initial Outlay $=\$ 400$, Depreciation $=$ MACRS 7-year, WACC $=10 \%$

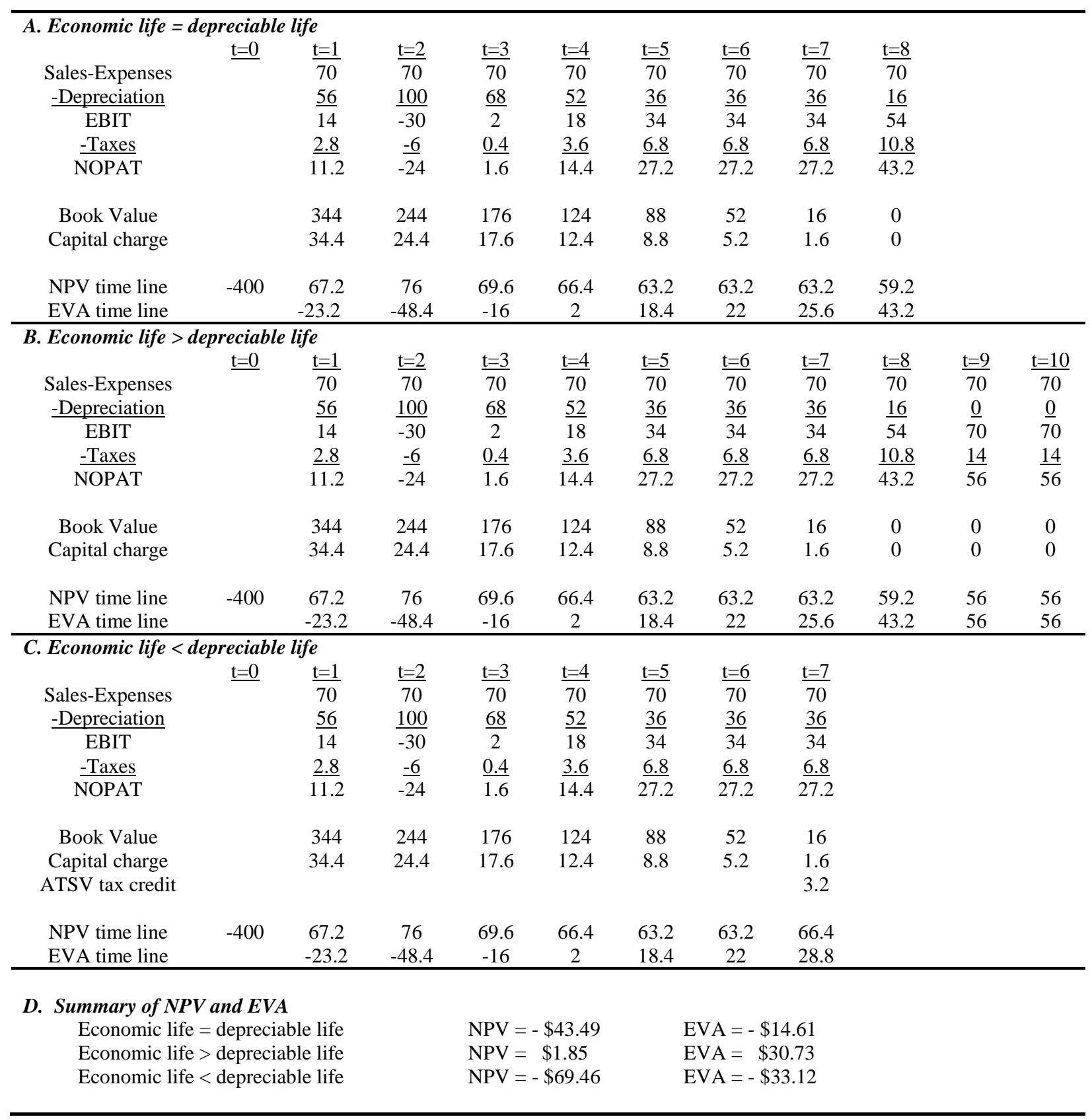

Average operating assets (AOA) for the capital charge

Table 3 summarizes the model's results when using average operating assets (AOA) for the capital charge. In some instances AOA might be considered the best choice as to an approximation of the true economic value of capital employed. When using a MACRS schedule it is possible to have an asset's book value equal to zero for a portion of the project's life, particularly for longer-lived projects that have assets depreciated on a short-term 
MACRS schedule. A zero book value results in a zero capital charge for those years, violating the true spirit of the capital charge. This situation does not occur when the capital charge is based on AOA because capital employed is always positive.

Similar to the previous section (end-of-year book values) the use of AOA produces conflicting capital budgeting decisions between EVA and NPV when the project's economic and depreciable lives are equal. The use of AOA in calculating the capital charge results in a smaller capital charge early in the project's life as compared to the other methods and larger charges later in the project's life. As would be expected, the conversion of the capital charge to what is essentially an annuity changes the timing of the cash flows and results in EVA becoming very sensitive to the chosen discount rate. Our hypothetical project has a larger EVA at a WACC equal to 10\%, but a larger NPV at a WACC equal to $2 \%$.

When the project's economic life is extended beyond its depreciable life the net effect is a reduction in EVA relative to NPV. For NPV, the impact of adding several years is extra NOPAT, but no change in depreciation expense. For EVA, the impact of adding several years is the additional NOPAT, but also an increase in the capital charge, or PV(-CC). The more years added, the greater the impact. For example, a project with a 5-year depreciable life but an economic life of 15 years gets a capital charge for all 15 years equal to the WACC multiplied by the average book value. Significant differences can be attained between the decision metrics if the project's economic life is substantially greater than its depreciable life.

If the project's economic life is less than its depreciable life both NPV and EVA lose PV(NOPAT) for the eliminated years. NPV loses PV $(+D)$ for the years removed while EVA loses PV $(-C C)$ for the years removed. Again both metrics fall in value, however NPV decreases at a faster rate due to the reduction in positive cash flows.

\section{Additional Capital Budgeting Issues}

In addition to uncertainties surrounding the computation of the capital charge, several other issues need to be considered before using EVA as a capital budgeting tool. These include 1) the timing and size of cash flows, 2) project salvage values, 3) changes in the weighted average cost of capital, 4) initial investment considerations, 5) training and R\&D expenditures, 6) risk adjustment procedures, and 7) investments in net working capital.

\section{Timing and size of cash flows}

Differences in the timing and size of project cash flows have been shown to potentially cause conflicts in ranking capital budgeting projects by the NPV and IRR criteria. Although not an issue in the case of independent projects, the disparity becomes important for mutually exclusive projects. Recall the equations for EVA and NPV (Equations $3 \mathrm{~b}$ and $4 \mathrm{~b}$ ). Both the timing and size of the cash inflows affect only NOPAT. Furthermore, EVA and NPV use the same discount rate, thus NPV-IRR type conflicts arising from differing reinvestment rate assumptions aren't applicable. Overall, the results of previous sections hold; decision makers need not be concerned with additional issues arising from the timing and/or size of a project's cash inflows.

\section{Positive salvage value}

Stewart (1991, pp. 86) defines NOPAT as "the total pool of profits available to provide a cash return to all financial providers of capital to the firm." On the basis of this definition, it is reasonable to assume that a project's after-tax salvage value (ATSV) would be included on the EVA time line during the year the cash inflow occurs. The addition of an after-tax salvage value to the NPV time line and the EVA time line is identical; hence it would cause no marginal differences between the two decision metrics. 
Table 3

Comparison of NPV and EVA using average operating assets for the capital charge Initial Outlay $=\$ 400$, Depreciation $=$ MACRS 7-year, WACC $=10 \%$

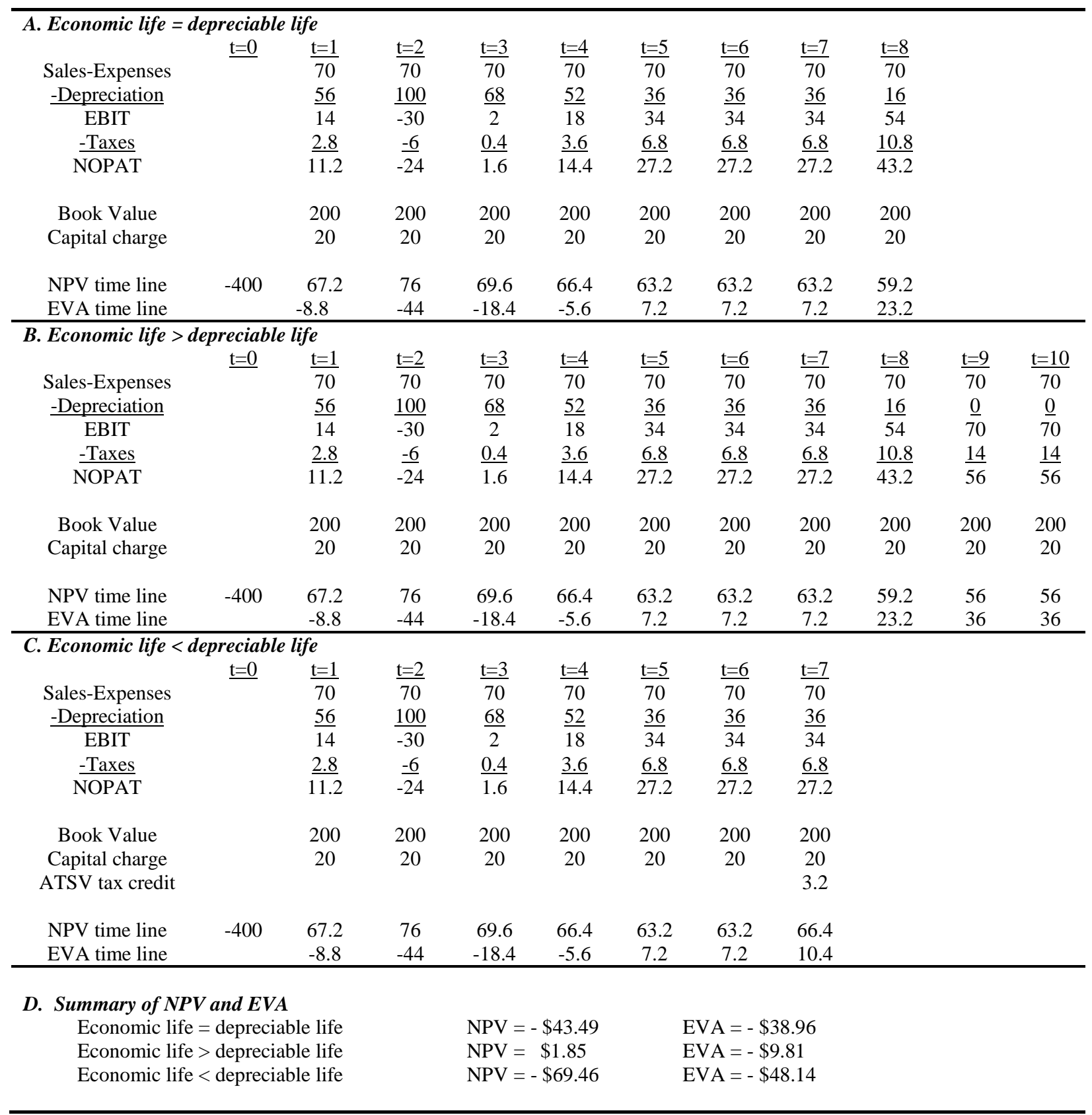

\section{Changes in the weighted average cost of capital}

Changes in the weighted average cost of capital do not impact -INV as it is a $t=0$ cash flow. Changes in WACC have similar effects on NPV and EVA through the PV(NOPAT) calculation; an increase in the cost of capital reduces NPV and EVA by identical amounts. The marginal impact of a change in WACC, therefore, depends on the change in PV(+D) for NPV and the change in PV(-CC) for EVA. In the NPV calculation, an 
increase in WACC will reduce the present value of depreciation having a negative marginal impact on NPV. Alternatively, the first derivative of NPV with respect to WACC is negative.

The marginal effect on EVA is also negative. Recall the capital charge is equal to WACC times capital employed. EVA deducts the present value of the project's annual capital charges as given by (7a) and (7b). Note that WACC appears in both the numerator and the denominator of the capital charge, and that capital employed is time-dependent.

$$
\begin{aligned}
& P V(C C)=\sum_{t=1}^{N} \frac{\text { CapitalEmployed }_{t} * \text { WACC }}{(1+\text { WACC })^{t}} \\
& P V(C C)=\sum_{t=1}^{N}\left(\text { CapitalEmployed }_{t} * \frac{W A C C}{(1+W A C C)^{t}}\right)
\end{aligned}
$$

The first derivative of (7a) or (7b) with respect to WACC is positive providing capital employed remains constant or decreases through time. ${ }^{9}$ This assumption is met for the three definitions of capital employed used in our analysis (end-of-year book values, beginning-of-year book values, or average operating assets), hence an increase in WACC increases the present value of the capital charge, causing EVA to decline.

Table 4 illustrates how changes in the weighted average cost of capital affect NPV and EVA. In Panel A the capital charge is based on beginning-of-year book values. We find an increase in WACC has no differential effect on NPV and EVA; both metrics decline by equivalent amounts. This is consistent with results in Table 1 that show NPV and EVA produce identical solutions when the capital charge is based on beginning-of-year book values and the project's economic life is greater than or equal to its depreciable life. In Panel B the capital charge is based on end-of-year book values. Again, an increase in WACC causes both metrics to decline, however EVA is greater than NPV for all positive costs of capital; that is, EVA declines at a slower rate. These results are consistent with those reported in Table 2 that show EVA exceeds NPV when the capital charge is based on end-of-year book values and the project's life is greater than or equal to its depreciable life. Finally Panel C illustrates the behavior of NPV and EVA as WACC is increased assuming AOA is used to compute the capital charge. In this model, the behavior of NPV and EVA are more erratic. While the metrics are equal at WACC $=0 \%$, their profiles cross between 5-10\%, leading to potentially conflicting capital budgeting decisions.

\section{Initial investment $\neq$ depreciable basis}

Thus far we have assumed that the project's initial investment is equal to its depreciable basis. Three situations whereby this may not be the case are 1) in a replacement situation where existing equipment will be sold, 2 ) if the project qualifies for an investment tax credit, or 3) if land is part of the up front cost. The first case is similar to our previous discussion on ATSV. The EVA time line should include the after-tax cash inflow from the sale at the time it occurs $(\mathrm{t}=0)$. The treatment of an investment tax credit is similar to the treatment of a cash inflow from the sale of old equipment. To avoid distortions away from NPV, one should compute the present value of the project's EVA and then adjust that value upward by the amount of the tax credit.

A project's initial investment will not equal its depreciable basis if land included as part of the up front cost (including both the purchase of land or recognizing the fair value of pre-owned land as an opportunity cost) since land is not a depreciable asset. The distinction between depreciable and non-depreciable assets would not affect the initial investment (-INV) in the NPV computation; both categories of assets are shown as cash outflows at the project's inception. 
Table 4

Comparison of NPV and EVA to changes in the weighted average cost of capital Initial Outlay $=\$ 400$, Depreciation $=$ MACRS 7-year, Economic life $=$ depreciable life

A. Capital charge based on beginning-of-year book values

$\begin{array}{llllllr} & \frac{0 \%}{128} & \underline{2 \%} & \underline{5 \%} & \underline{50 \%} & \underline{15 \%} & \underline{20 \%} \\ \text { NAP } & 128.77 & 29.35 & -43.49 & -98.51 & -140.95 \\ \text { EVA } & 128 & 84.77 & 29.35 & -43.49 & -98.51 & -140.95\end{array}$

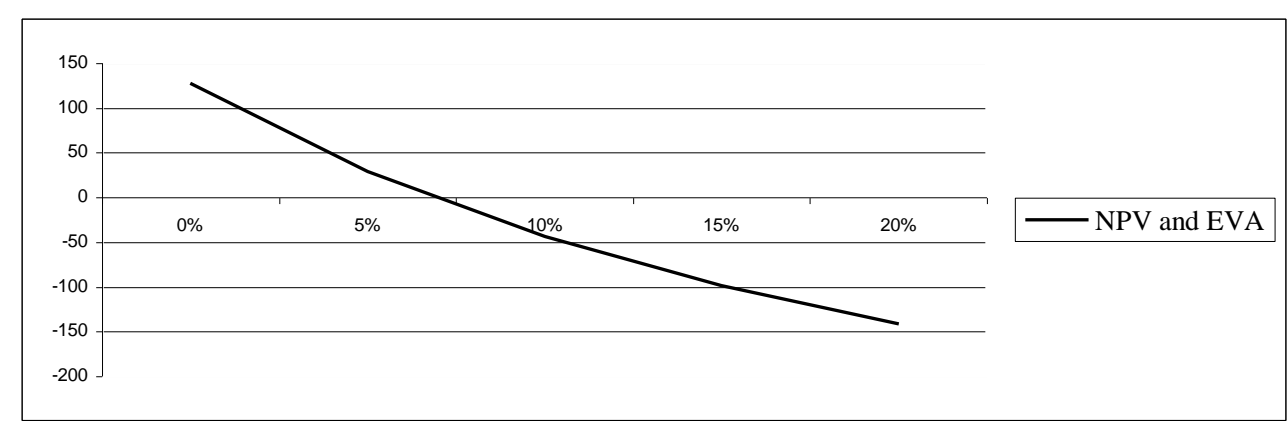

B. Capital charge based on end-of-year book values

$\begin{array}{lllllll} & \underline{0 \%} & \underline{2 \%} & \underline{5 \%} & \underline{10 \%} & \underline{15 \%} & \underline{20 \%} \\ \text { NPV } & 128 & 84.77 & 29.35 & -43.49 & -98.51 & -140.95 \\ \text { EVA } & 128 & 92.22 & 46.2 & -14.61 & -60.87 & -96.79\end{array}$

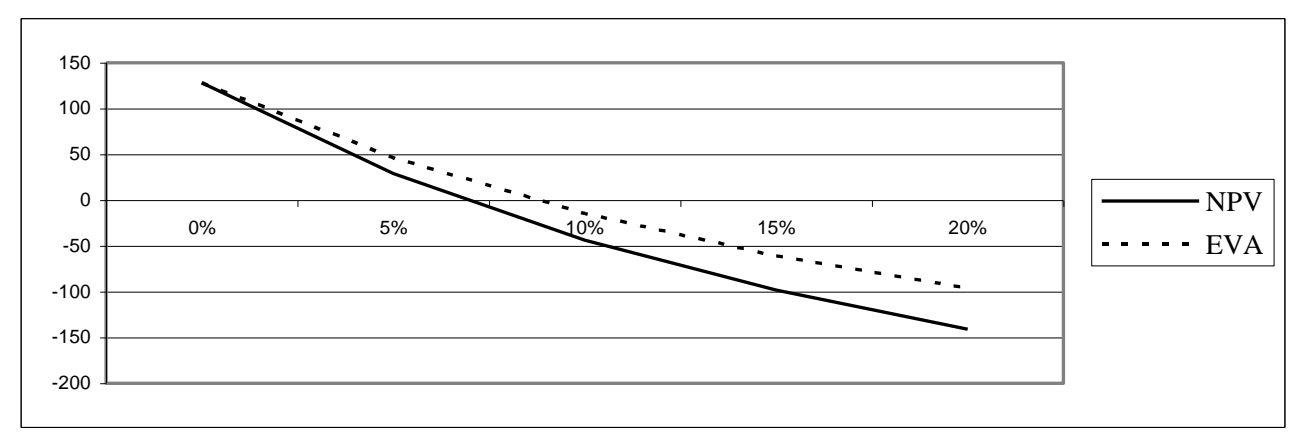

C. Capital charge based on average operating assets

\begin{tabular}{llllllr} 
& $\underline{0 \%}$ & $\underline{2 \%}$ & $\underline{5 \%}$ & $\underline{10 \%}$ & $\underline{15 \%}$ & $\underline{20 \%}$ \\
NPV & 128 & 84.77 & 29.35 & -43.49 & -98.51 & -140.95 \\
EVA & 128 & 82.72 & 27.67 & -38.96 & -84.11 & -115.27 \\
\hline
\end{tabular}

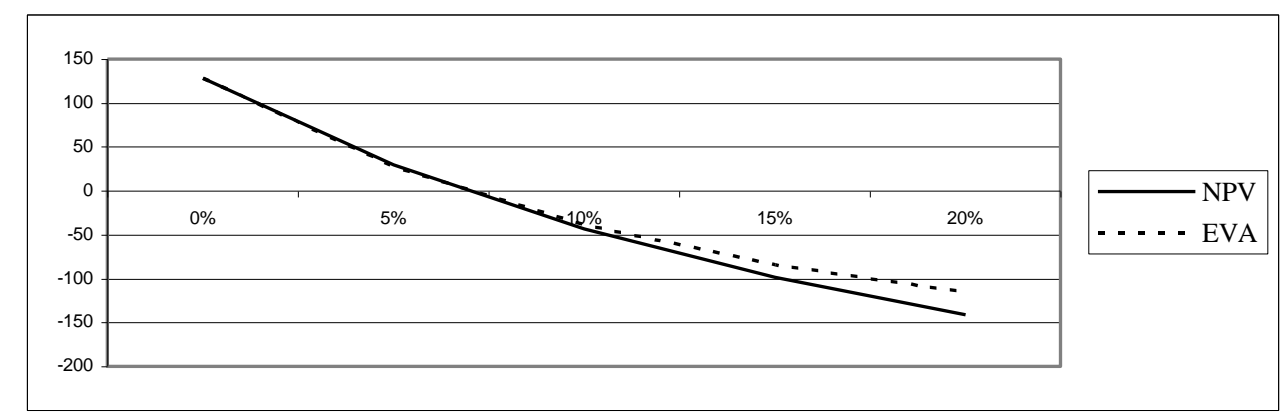


Because land is not depreciated, it would have no effect on cash flows beyond $t=0$. EVA would capitalize the cost of the land and assign a capital charge against it for each year of the project's life. Both metrics would decline given the purchase of land. Which metric declines more would depend on the project's WACC and the project's life. Recall land is not depreciated, hence the annual capital charge is an annuity equal to WACC times the cost of the land. EVA would decline more than NPV for long-lived projects that are assigned high costs of capital, as these projects would have a large capital charge levied over an extended time period. At some point, the present value of the capital charge could exceed the initial cost of the land.

\section{Training and $R \& D$ expenses}

Training and R\&D expenditures may be treated very differently in an EVA-based analysis. In fact, one of EVA's distinguishing features is that adjustments are made for cash expenditures that are expected to provide future benefits. For example, EVA recommends capitalizing (at least portions of) R\&D and training expenses for compensation and performance measurement purposes (Burkette and Hedley, 1997). The intent is to remove an accounting distortion on income caused by expenses that will ultimately impact income beyond one year. Although sunk costs are excluded for capital budgeting analyses, the fact that EVA proponents do capitalize some of these expenses in other situations (compensation and performance evaluation), may suggest their inclusion in capital budgeting.

Table 5 first illustrates the marginal impact of training expenses on NPV. Assuming training expenses of $\$ 125$ to be incurred at $\mathrm{t}=0$ and a tax rate of $20 \%$, we find that NPV falls by the after-tax amount of the expense, or by $\$ 100$ at $t=0$. In contrast, EVA capitalizes the expense. To do this, training expenses are added back, net of any tax effects, in the year they were deducted on the income statement. The net effect in our example is to eliminate the cash outflow at $\mathrm{t}=0$. Assuming the expense is capitalized over the project's entire life, NOPAT decreases each year by the amount of the annualized expense $(\$ 125 / 10=\$ 12.50$ each year for $\mathrm{t}=1,2, \ldots 10)$. Finally, the capital charge increases each period based on the asset's book value. We assume straight-line depreciation and use end-ofyear book values for the capital charge, as this method seems most consistent with the annual adjustments made to NOPAT. In our example, the present value of the incremental cash flows (at 10\%) is equal to - $\$ 100$ for NPV and $\$ 117.32$ for EVA. In general, the impact of training expenses on EVA depends on the firm's WACC. At a 5\% WACC the present value of incremental cash flows for EVA is $-\$ 143.83$; at a $20 \%$ WACC EVA falls by $-\$ 83.46$. The impact on NPV is $-\$ 100$ regardless of the discount rate.

Research and development expenditures also pose a problem to the analysis, albeit in a much different manner. Standard capital budgeting practices call for eliminating sunk costs from the analysis, thus R\&D expenditures would not be deducted on a net present value cash flow time line. EVA users, however, may capitalize and expense R\&D costs similar to the procedure used for training expenses. ${ }^{10}$ These types of "expense-related" distortions between NPV and EVA may be further exaggerated, depending on the length of time the expense is capitalized. Ehrbar (1998) notes that the correct amortization period can range from as little as three or four years for R\&D expenditures on scientific instruments to eight or more years for $R \& D$ expenditures on pharmaceuticals. The average useful life of $R \& D$ for all industries is five years. Although these guidelines are offered within the context of overall firm-level EVA computations, the issue also applies to capital budgeting decisions as there are no rules stating these types of expenses must be amortized over a period exactly equal to the project's life. The choice, however, can have a significant impact; shorter amortization periods cause larger declines in EVA.

\section{Risk adjustment}

For capital budgeting purposes, WACC is considered appropriate for average-risk projects or those with the same risk and capital structure as the firm's existing assets. For projects with higher- or lower-than-average risk, or different debt capacity, some adjustment is needed. One adjustment used in net present value analysis is to employ a risk-adjusted discount rate (RADR) when computing the present value of the project's cash flows. ${ }^{11}$ 
Table 5

Comparison of NPV and EVA with training expenses

Straight line depreciation, end-of-year book values for the capital charge, WACC $=10 \%$, Training expense $=\$ 125$ at $\mathrm{t}=0$, Tax rate $=20 \%$
A. Net Present Value

After-tax expense $\quad \frac{\mathrm{t}=0}{-100} \quad \underline{\mathrm{t}=1} \quad \underline{\mathrm{t}=2} \quad \underline{\mathrm{t}=3} \quad \underline{\mathrm{t}=4} \quad \underline{\mathrm{t}=5} \quad \underline{\mathrm{t}=6} \quad \underline{\mathrm{t}=7} \quad \underline{\mathrm{t}=8} \quad \underline{\mathrm{t}=9} \quad \underline{\mathrm{t}=10}$
$\mathrm{PV}(10 \%)=-\$ 100$

B. Economic Value Added

\begin{tabular}{|c|c|c|c|c|c|c|c|c|c|c|c|}
\hline & $\mathrm{t}=0$ & $\mathrm{t}=1$ & $\mathrm{t}=2$ & $\mathrm{t}=3$ & $\mathrm{t}=4$ & $\mathrm{t}=5$ & $\mathrm{t}=6$ & $\mathrm{t}=7$ & $\mathrm{t}=8$ & $\mathrm{t}=9$ & $\mathrm{t}=10$ \\
\hline$\triangle \mathrm{NOPAT}$ & 0 & $-\overline{12.5}$ & $-\overline{12.5}$ & $-\overline{12.5}$ & $-\overline{12.5}$ & $-\overline{12.5}$ & $-\overline{12.5}$ & $-\overline{12.5}$ & $-\overline{12.5}$ & $-\overline{-12.5}$ & $\overline{-12.5}$ \\
\hline$\Delta \mathrm{CC}$ & $\underline{0}$ & $\underline{-11.25}$ & -10 & $\underline{-8.75}$ & -7.5 & $\underline{-6.25}$ & $\underline{-5}$ & -3.75 & $\underline{-2.5}$ & $\underline{-1.25}$ & $\underline{0}$ \\
\hline$\overline{\Delta \text { Total }}$ & $\overline{0}$ & -23.75 & $-\overline{22.5}$ & $-\overline{21.25}$ & $\overline{-20}$ & $-\overline{18.75}$ & $-1 \overline{7} .5$ & $\overline{-16.25}$ & -15 & $-\overline{-13.75}$ & $-1 \overline{2} .5$ \\
\hline
\end{tabular}

$\operatorname{PV}(10 \%)=-\$ 117.32$

While the same technique can be used for EVA, there are additional considerations as the firm's WACC appears in the computation of the capital charge as well as the discount rate. Essentially, there are three options when correcting EVA for risk: (1) adjust WACC up (down) for both the capital charge and the discount rate; (2) adjust WACC up (down) for just the discount rate; and (3) adjust WACC up (down) for just the capital charge. ${ }^{12}$

Table 6 provides an example comparing these alternatives. As expected, option (1), or adjusting WACC up (down) for both the capital charge and discount rate, has the most significant impact. A higher WACC increases the periodic capital charge and reduces the present value of NOPAT. ${ }^{13}$ In our example EVA ranges from a high value of $\$ 240.00$ (WACC $=0 \%$ ) to a low value of $-\$ 76.89$ (WACC $=20 \%$ ). Adjustments to just the discount rate or to just the capital charge have similar effects to one another. Both produce a smaller variation in EVA when compared to option (1).

Changes to either the discount rate or the capital charge could have very different effects under other circumstances. The capital charge in Table 6 is based on end-of-year book values. Furthermore, the example assumes the project has an economic life of ten years, greater than its depreciable life of seven years. During the final three years of the project's life the asset's book value, and thus capital charge, are equal to zero. In this case risk adjustments to the discount rate affect cash flows in all years via the impact on PV(NOPAT), however risk adjustments to the interest rate applied to the capital charge have no effect on the project's cash flows at $t=8,9,10$. The relationship between a project's economic and depreciable life would be much less important if the firm were to use average operating assets for its capital charge; the project would have a positive capital charge in each year and adjustments to the capital charge interest rate would affect project cash flows in all periods. We believe option (1) is probably the most realistic of the three. Obviously WACC should be increased to deal with increased risk when using a RADR approach. The capital charge should be viewed as a cost or charge for using capital. If a project has higher than average risk then that fee should also be higher. Alternatively, a project that was considered on a standalone basis (treated as an independent mini-firm) would have to pay the higher cost of capital in order to obtain funds for investment. 
Table 6

Comparison of NPV and EVA with risk-adjusted discount rates Initial Outlay $=\$ 400$, MACRS 7-year property class, Project life $=10$ years,

WACC $=10 \%$, end-of-year book values for the capital charge

\begin{tabular}{|c|c|c|c|c|c|c|c|c|c|c|}
\hline & $\mathrm{t}=1$ & $\mathrm{t}=2$ & $\underline{\mathrm{t}=3}$ & $\underline{\mathrm{t}=4}$ & $\mathrm{t}=5$ & $\underline{t=6}$ & $\mathrm{t}=7$ & $\underline{\mathrm{t}=8}$ & $\mathrm{t}=9$ & $\mathrm{t}=10$ \\
\hline Sales & 100 & 100 & 100 & 100 & 100 & 100 & 100 & 100 & 100 & 100 \\
\hline -Expenses & 30 & 30 & 30 & 30 & 30 & 30 & 30 & 30 & 30 & 30 \\
\hline -Depreciation & $\underline{56}$ & $\underline{100}$ & $\underline{68}$ & $\underline{52}$ & $\underline{36}$ & $\underline{36}$ & $\underline{36}$ & $\underline{16}$ & $\underline{0}$ & $\underline{0}$ \\
\hline EBIT & $\overline{14}$ & -30 & $\overline{2}$ & 18 & 34 & 34 & 34 & $\overline{54}$ & 70 & $\overline{70}$ \\
\hline -Taxes & 2.8 & $\underline{-6}$ & $\underline{0.4}$ & 3.6 & 6.8 & 6.8 & 6.8 & 10.8 & 14 & 14 \\
\hline$\overline{\text { NOPAT }}$ & $\overline{11.2}$ & $-\overline{24}$ & $\overline{1.6}$ & $\overline{14.4}$ & $\overline{27.2}$ & $\overline{27.2}$ & $\overline{27.2}$ & $\overline{43.2}$ & $\overline{56}$ & $\overline{56}$ \\
\hline \multirow[t]{6}{*}{ Book Value } & 344 & 244 & 176 & 124 & 88 & 52 & 16 & 0 & 0 & 0 \\
\hline & & $\underline{0 \%}$ & $2 \%$ & & $5 \%$ & $10 \%$ & $15 \%$ & \multicolumn{2}{|c|}{$20 \%$} & \\
\hline & NPV & 240 & 177.57 & & $9 \overline{99.83}$ & 1.85 & $-\overline{-68.75}$ & \multicolumn{2}{|c|}{-121.06} & \\
\hline & $\begin{array}{c}\text { EVA } \\
\text { (Option 1) }\end{array}$ & 240 & 185.02 & & 116.68 & 30.73 & -31.11 & \multicolumn{2}{|c|}{-76.89} & \\
\hline & $\begin{array}{c}\text { EVA } \\
\text { (Option 2) }\end{array}$ & 135.6 & 105.66 & & 70.57 & 30.73 & 6.02 & \multicolumn{2}{|c|}{-9.39} & \\
\hline & $\begin{array}{c}\text { EVA } \\
\text { (Option 3) }\end{array}$ & 113.08 & 96.61 & & 71.9 & 30.73 & -10.45 & \multicolumn{2}{|c|}{-51.62} & \\
\hline
\end{tabular}

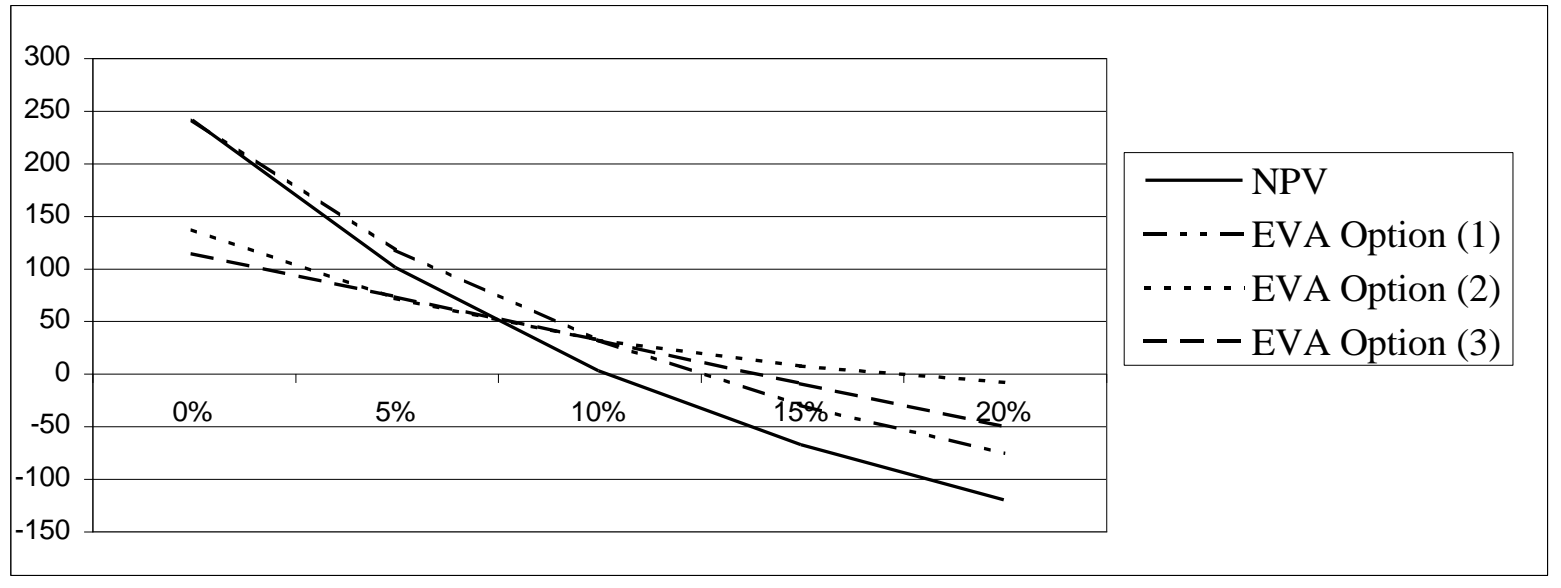

Option (1): Adjust both the discount rate and the interest rate applied to the capital charge.

Option (2): Adjust the discount rate. The interest rate applied to the capital charge remains at $10 \%$.

Option (3): Adjust the interest rate applied to the capital charge. The discount rate remains at $10 \%$.

\section{Changes in net working capital}

Interestingly, some project-induced changes in a firm's net working capital (NWC) will not cause any differences between NPV and EVA, despite their very different treatment. To see this assume a simple capital budgeting project that requires an increase in the firm's NWC at $\mathrm{t}=0$. Full recovery at the end of the project's life is 
expected. NPV treats the increase in NWC as a cash outflow at the project's inception and a cash inflow at the end of the project's life. The impact on the project's NPV is given by Equations (8a) and (8b).

$$
\begin{aligned}
& \Delta N P V=-N W C+\frac{N W C}{(1+W A C C)^{N}} \\
& \Delta N P V=-N W C *\left[1-\frac{1}{(1+W A C C)^{N}}\right]
\end{aligned}
$$

Multiplying the right hand side of Equation ( $8 \mathrm{~b}$ ) by WACC/WACC and rearranging yields:

$$
\begin{aligned}
& \frac{\triangle N P V}{-N W C}=\frac{W A C C}{W A C C}-\frac{W A C C}{W A C C *(1+W A C C)^{N}} \\
& \frac{\triangle N P V}{-N W C}=W A C C *\left[\frac{1}{W A C C}-\frac{1}{W A C C *(1+W A C C)^{N}}\right]
\end{aligned}
$$

The term in brackets is simply equal to the present value interest factor of an annuity and is multiplied by the firm's WACC, as given by Equation (8e).

$$
\frac{\triangle N P V}{-N W C}=W A C C *\left(P V I F A_{W A C C, N}\right)
$$

EVA treats the investment in net working capital similar to an increase in the firm's fixed assets. The increase is considered a capital investment, and a capital charge is levied against that amount throughout the project's life. Unlike an investment in fixed assets there is no depreciation to consider on the firm's current assets. As a result, the capital charge is simply an annuity equal to the increase in NWC times WACC. EVA declines by the present value of this annuity, as illustrated by Equations (9a) or (9b). A comparison of (8e) and (9b) illustrates that, in this example, changes in net working capital affect NPV and EVA identically.

$$
\triangle E V A=\sum_{t=1}^{N} \frac{-N W C * W A C C}{(1+W A C C)^{t}}
$$

个

$$
\frac{\Delta E V A}{-N W C}=W A C C *\left(P V I F A_{W A C C, N}\right)
$$

This result extends to more general treatments of net working capital, assuming the investment in net working capital is fully recovered (see Appendix B for the proof). If the total investment in net working capital is not recovered by the end of the project's life then EVA will be biased upward relative to NPV (EVA>NPV); thus EVA may accept a project that would be rejected by NPV.

\section{Discussion}

A summary of the scenario analyses comparing NPV and EVA are presented in Table 7. We find that NPV and EVA yield identical capital budgeting solutions only under the following very restrictive assumptions: 1) the project's economic life is greater than or equal to its depreciable life, 2) beginning-of-year book values are used for the capital charge, 3) land is not part of the project's up-front cost, 4) R\&D and training expenses equal zero, 5) the 
project has the same level of risk as the firm's overall assets, and 6) the investment in net working capital is fully recovered. Generally, NPV and EVA produce different statistics raising the likelihood of conflicting decision rules. Our analysis indicates that R\&D, training expenses, risk-adjustments, land purchases, and NWC treatment can produce significant distortions between NPV and EVA, if not accounted for properly. While some of these concerns call for a fairly straightforward adjustment, and have a marginal impact on the analysis (at most), others have the potential to produce significant variations between NPV and EVA.

Table 7

Summary of NPV and EVA comparisons under various capital budgeting scenarios

Economic life $=$ depreciable life
Economic life $>$ depreciable life
Economic life $<$ depreciable life
Timing and size of cash flows
New project salvage value
Change in WACC
Replacement project salvage value
Investment tax credit
Land purchase
Training expenses
R\&D expenses
Risk adjustments
Net working capital

BOY BV = Beginning-of-year book value used for the capital charge EOY BV = End-of-year book value used for the capital charge $\mathrm{AOA}=$ Average operating assets used for the capital charge

EOY BV
NPV $<$ EVA
NPV $<$ EVA
NPV $<$ EVA
No effect
No effect
NPV $<$ EVA
No effect
No effect
NPV $><$ EVA
NPV $><$ EVA
NPV $>$ EVA
NPV $><$ EVA
NPV $\leq$ EVA

\section{Conclusion}

EVA continues to be promoted in the popular press as a superior measure of firm value and as a superior tool for constructing value-maximizing management compensation systems. A recent article in Fortune magazine reports that Stern Stewart claims their clients posted average annual returns of $21.8 \%$, compared to $13 \%$ earned by firms of similar market capitalization. Despite claims that EVA is theoretically congruent to NPV, there has yet to be an empirical examination of the issue. This paper presents a preliminary examination of the relationship between EVA and NPV as capital budgeting decision tools. We find that NPV and EVA are not equivalent in most normal capital budgeting situations.

\section{Suggestions for Future Research}

Despite its growing popularity, it is clear that more research is needed before EVA will replace NPV or IRR as a firm's capital budgeting decision criteria. Of particular importance is determining an appropriate value for computing the capital charge. What are the pros and cons of using book values? Does the book value for the capital charge need to follow the same depreciation schedule used for computing NOPAT? Or is it appropriate to use some other measure such as average operating assets as suggested by Dillon and Owers (1997)? Studies by Bacidore, Boquist, Milbourn, and Thakor (1997), Kramer and Pushner (1997), and Grant (1996) have examined the potential use of market value measures in estimating capital charges; this strategy should also be explored within the capital budgeting context. 
Future research also needs to examine the appropriate adjustments to EVA for differential project risk. Specifically, should higher project risk necessitate a higher discount rate, a higher capital charge, or both? Finally, Stewart has identified more than 150 possible adjustments to reported accounting earnings to eliminate distortions away from true economic performance. While some of these are relevant only when using EVA to measure firm performance as a whole, many are related to capital budgeting practices, hence their effects need to be considered. As found by Weaver (2001), significant discrepancies exist among current EVA users and the application of these adjustments when using EVA as a firm-level performance metric; one would expect similar discrepancies within a capital budgeting context.

\section{Endnotes}

1. See http://www.sternstewart.com/evaabout/evacomp.shtml for a partial listing of Stern Stewart EVA clients.

2. When computing EVA adjustments to both NOPAT and capital employed are made in order to eliminate (or reduce) non-economic accounting and financing conventions. Essentially, equity equivalent reserves are added to capital while periodic changes in the reserves are added to after-tax operating profits (Stewart, 1991, pp. 112-127). Examples of equivalent reserves are deferred income tax reserves, LIFO reserves, cumulative amortization of goodwill, capitalized intangibles such as R\&D, allowance for doubtful accounts, and reserves for warranty claims. After-tax interest expense is also added back to income to eliminate the effect of leverage on the income statement. On the balance sheet, reserves associated with NOPAT adjustments are considered equity equivalents and included as part of capital. Thus, certain expenditures (research and development and employee training expenses) are capitalized and amortized over time rather than expensed in the year incurred.

3. Capital employed (economic book value) includes investments in net working capital and fixed assets (Ehrbar, 1998, pp. 131 and 177).

4. See Abdeen and Haight (2002) for an example of the cost of capital computation.

5. A recent article by Weaver (2001) surveyed 29 EVA users. He applied each respondent firm's stated approach for computing "net asset value" to a set of hypothetical financial statements and finds 15 different net asset values, all unique from the "theoretical" EVA value. In fact, he finds that none of the respondents measured EVA, NOPAT, or capital employed in the same way.

6. Damodaran (undated) makes three critical assumptions to prove the equivalency of NPV and EVA. First, the annual capital charge is an annuity equal to the weighted average cost of capital times the project's initial investment or CC=WACC*INV. The annual capital charge is not based on the project's actual book value in each year, or on average operating assets, as our model assumes. Second, the project earns exactly the cost of capital and allows for the entire investment to be salvaged at the end of the project's life or $\mathrm{INV}=\mathrm{PV}(\mathrm{CC})+\mathrm{PV}(\mathrm{INV})$. Finally, the present value of depreciation is equal to the present value of the initial investment discounted to $t=0$, or $P V(D)=P V(I N V)$. Combining the latter two equations yields $\mathrm{PV}(\mathrm{D})+\mathrm{PV}(\mathrm{CC})+\mathrm{INV}$, which is the same as our equation $(5 \mathrm{~b})$. However, our model and Damodaran's model will produce identical results only for a 1-year project where our capital charge is based on the beginning-of-year book value. In that case, the $\mathrm{t}=1$ capital charge is equal to WACC*INV, similar to Damodaran's assumption. For longer-lived projects, our capital charge declines after $t=1$ as the book value of the asset declines while the capital charge remains constant in Damodaran's model. Overall, the assumptions made by each model, particularly with respect to the computation of the annual capital charge, preclude a direct comparison to one another.

7. The proof is provided in Appendix A.

8. We assume that the firm would use the same depreciation schedule, regardless of its choice of EVA or NPV, thus the asset would have the same book value at the end of the economic life. The tax credit would be identical for both decision metrics, and would not cause any differential impact.

9. The proof is available from the authors on request.

10. Obviously if EVA-users treat R\&D as a sunk cost, as is typical in capital budgeting, then EVA and NPV will not differ on this issue.

11. Risk adjustment can also be handled via the certainty equivalent method (Brigham, Gapenski, and Daves, 1999, Chapter 8). 
12. In our prior sensitivity analysis of WACC we adjusted both. We did not adjust the firm's WACC up or down for risk, however, we simply computed EVA for various WACCs.

13. Increasing the discount rate will offset part of the increase in the capital charge caused by the upward riskadjustment. As noted (see Equations $7 \mathrm{a}$ and $7 \mathrm{~b}$ and their discussion) the net effect is an increase in the present value of the capital charge as long as capital employed either remains constant or declines through time.

\section{References}

1. Abdeen, Adnan M. and G. Timothy Haight, "A Fresh Look at Economic Value Added: Empirical Study of the Fortune Five-Hundred Companies," Journal of Applied Business Research, Vol. 18, No. 2, pp. 27-36, 2002.

2. Bacidore, Jeffrey M., John A. Boquist, Todd T. Milbourn, and Anjan V. Thakor, "The Search for the Best Financial Performance Measure," Financial Analysts Journal, Vol. 53, pp. 11-20, 1997.

3. Barfield, Richard, "Nearly New," Accountancy, Vol. 121, No. 1253, pp. 41, 1998.

4. Biddle, Gary C., Robert M. Bowen and James S. Wallace, "Does EVA Beat Earnings? Evidence on the Associations with Stock Returns and Firm Values," Journal of Accounting and Economics, Vol. 24, No. 3. pp. 301-336, 1997.

5. Brigham, Eugene F.., Louis C. Gapenski, and Phillip R. Daves, Intermediate Financial Management, $6^{\text {th }}$ Ed., The Dryden Press, Fort Worth TX, 1999.

6. Burkette, Gary D. and Timothy P. Hedley, "The Truth about Economic Value Added," The CPA Journal, Vol. 67, No. 7, pp. 46-49, 1997.

7. Chen, Shimin and James L. Dodd, "Economic Value Added: An Empirical Examination of a New Corporate Performance Measure," Journal of Managerial Issues, Vol. 9, No. 3, pp. 318-333, 1997.

8. Clinton, B. Douglas and Shimin Chen, "Do New Performance Measures Measure Up?" Management Accounting, Vol. 80, No. 4, pp. 38-43, 1998.

9. Damodaran, Answath. "Economic Value Added," http://www.stern.nyu.edu/ adamodar/

10. de Villiers, Johann, "The Distortions in Economic Value Added (EVA) Caused by Inflation," Journal of Economics and Business, Vol. 49, No. 3, pp. 285-300, 1997.

11. Dillon, Ray D. and James E. Owers, "EVA as a Financial Metric: Attributes, Utilization, and Relationship to NPV," Financial Practice and Education, Vol. 7, No. 1, pp. 32-40, 1997.

12. Dodd, James and Shimin Chen, "Economic Value Added (EVA)," Arkansas Business and Economic Review, Vol. 30, No. 4, pp. 1-8, 1997.

13. Ehrbar, Al, "Using EVA to Measure Performance and Assess Strategy," Strategy \& Leadership, Vol. 27, No. 3, pp. 2024, 1999.

14. Ehrbar, Al, EVA. The Real Key to Creating Wealth, John Wiley \& Sons, Inc., New York NY, 1998.

15. Grant, James L., "Foundations of EVA for Investment Managers: Just in Time, EVA!" Journal of Portfolio Management, Vol. 23, No. 1, pp. 41-48, 1996.

16. Kramer, Jonathan K. and George Pushner, "An Empirical Analysis of Economic Value Added as a Proxy for Market Value Added," Financial Practice and Education, Vol. 7, No. 1, pp. 41-49, 1997.

17. Lavin, Angeline M. and Thomas S. Zorn, "The Impact of Economic Depreciation on the Abandonment Option: A Guide for Practitioners," Financial Practice and Education, Vol. 10, No. 2, pp. 92-100, 2000.

18. Lehn, Kenneth and Anil K. Makhija, "EVA \& MVA as Performance Measures and Signals for Strategic Change," Strategy \& Leadership, Vol. 24, No. 3, pp. 34-38, 1996.

19. Lehn, Kenneth and Anil K. Makhija, "EVA, Accounting Profits, and CEO Turnover: An Empirical Examination, 19851994," Journal of Applied Corporate Finance, Vol. 10, No. 2, pp. 90-97, 1997.

20. O’Byrne, Stephen F., "EVA and Shareholder Return," Financial Practice and Education, Vol. 7, No. 1, pp. 50-54, 1997.

21. Olsen, Eric E., "Economic Value Added," Perspectives, Boston Consulting Group, Boston, MA, 1996.

22. Peterson, Pamela P. and David R. Peterson, "Company Performance and Measures of Value Added," The Research Foundation of the Institute of Chartered Financial Analysts, Charlottesville, VA, 1996.

23. Rogerson, William P., "Intertemporal Cost Allocation and Managerial Investment Incentives: A Theory Explaining the Use of Economic Value Added as a Performance Measure," Journal of Political Economy, Vol. 105, No. 4, pp. 770$795,1997$.

24. Ryan, Harley E. and Emery A. Trahan, "The Utilization of Value-Based Management: An Empirical Analysis," Financial Practice and Education, Vol. 9, No. 1, pp. 46-58, 1999.

25. Stern, Joel M., G. Bennett Stewart III, and Donald H. Chew, Jr., "The EVA Financial System," Journal of Applied Corporate Finance, Vol. 8, No. 2, pp. 32-46, 1995.

26. Stewart III, G. Bennett, The Quest for Value, HarperCollins, Publishers Inc., New York NY, 1991. 
27. Stewart III, G. Bennett, "EVA: Fact and Fantasy,” Journal of Applied Corporate Finance, Vol. 7, No. 2, pp. 71-84, 1994.

28. Tully, Shawn, “The EVA Advantage,” Fortune Magazine, Vol. 135, pp. 210, 1999.

29. Wallace, James S., “Adopting Residual Income-Based Compensation Plans: Do You Get What You Pay For?” Journal of Accounting and Economics, Vol. 24, pp. 275-300, 1997.

30. Weaver, Samuel C., "Measuring Economic Value Added: A Survey of the Practices of EVA Proponents," Journal of Applied Finance, Vol. 11, No. 1, pp. 50-60, 2001.

31. Young, S. David, "Some Reflections on Accounting Adjustments and Economic Value Added," Journal of Financial Statement Analysis, Vol. 4, No. 2, pp. 7-19, 1999.

\section{Appendix A}

NPV and EVA can be expressed as:

$$
\begin{aligned}
& N P V=\sum_{t=1}^{N} \frac{\left(S_{t}-X_{t}-D_{t}\right)(1-T)+D_{t}}{(1+k)^{t}}-I N V \\
& E V A=\sum_{t=1}^{N} \frac{\left(S_{t}-X_{t}-D_{t}\right)(1-T)}{(1+k)^{t}}-\sum \frac{C C_{t}}{(1+k)^{N}}
\end{aligned}
$$

NPV will equal EVA if:

$$
\begin{aligned}
& \sum_{t=1}^{N} \frac{D_{t}}{(1+k)^{t}}-I N V=\sum \frac{-C C_{t}}{(1+k)^{t}} \\
& \sum \frac{D_{t}}{(1+k)^{t}}+\sum \frac{C C_{t}}{(1+k)^{t}}=I N V \\
& P V(D)+P V(C C)=I N V
\end{aligned}
$$

Assume: Salvage value=0; fully depreciated asset; beginning-of-year book values for the capital charge; 3 year project life with Year 1 capital charge $=k\left(D_{1}+D_{2}+D_{3}\right)$, Year 2 capital charge $=k\left(D_{2}+D_{3}\right)$, and Year 3 capital charge $=\mathrm{k}\left(\mathrm{D}_{3}\right)$.

Proof: $\quad P V(D)+P V(C C)=I N V$

$$
\begin{aligned}
& \frac{D_{1}+k\left(D_{1}+D_{2}+D_{3}\right)}{(1+k)^{1}}+\frac{D_{2}+k\left(D_{2}+D_{3}\right)}{(1+k)^{2}}+\frac{D_{3}+k D_{3}}{(1+k)^{3}}=I N V \\
& \frac{D_{1}(1+k)+k\left(D_{2}+D_{3}\right)}{(1+k)^{1}}+\frac{D_{2}(1+k)+k D_{3}}{(1+k)^{2}}+\frac{D_{3}(1+k)}{(1+k)^{3}}=I N V \\
& D_{1}+\frac{k\left(D_{2}+D_{3}\right)}{(1+k)^{1}}+\frac{D_{2}}{(1+k)^{1}}+\frac{k D_{3}}{(1+k)^{2}}+\frac{D_{3}}{(1+k)^{2}}=I N V \\
& D_{1}+\frac{k D_{2}}{(1+k)^{1}}+\frac{k D_{3}}{(1+k)^{1}}+\frac{D_{2}}{(1+k)^{1}}+\frac{k D_{3}}{(1+k)^{2}}+\frac{D_{3}}{(1+k)^{2}}=I N V \\
& D_{1}+\left[\frac{k D_{2}}{(1+k)^{1}}+\frac{D_{2}}{(1+k)^{1}}\right]+\left[\frac{k D_{3}}{(1+k)^{1}}+\left(\frac{k D_{3}}{(1+k)^{2}}+\frac{D_{3}}{(1+k)^{2}}\right)\right]=I N V \\
& D_{1}+\frac{D_{2}(1+k)}{(1+k)^{1}}+\frac{k D_{3}}{(1+k)^{1}}+\frac{D_{3}(1+k)}{(1+k)^{2}}=I N V
\end{aligned}
$$




$$
\begin{aligned}
& D_{1}+D_{2}+\frac{k D_{3}}{(1+k)^{1}}+\frac{D_{3}}{(1+k)^{1}}=I N V \\
& D_{1}+D_{2}+\frac{D_{3}(1+k)}{(1+k)^{1}}=I N V \\
& D_{1}+D_{2}+D_{3}=I N V
\end{aligned}
$$

\section{Appendix B}

Let $\mathrm{NWC}_{\mathrm{t}}$ equal the level of investment in the firm's net working capital in a capital budgeting project at time t. Note that the level of net working capital at time zero is equal to the change in net working capital from the preproject period. In subsequent periods the change in net working capital, attributable to the project, is equal to $\mathrm{NWC}_{\mathrm{t}}-\mathrm{NWC}_{\mathrm{t}-1}$.

The NPV of a project varies by the present value of future changes in net working capital. NPV's treatment of net working capital can be expressed as

$$
-N W C_{0}+\frac{\left(N W C_{0}-N W C_{1}\right)}{(1+k)^{1}}+\frac{\left(N W C_{1}-N W C_{2}\right)}{(1+k)^{2}}+\frac{\left(N W C_{2}-N W C_{3}\right)}{(1+k)^{3}}
$$

The EVA of a project varies by the present value of the capital charge caused by the level of net working capital. Assuming the capital charge at time $t$ is levied against the level of net working capital at the beginning of period $t$, EVA's treatment of net working capital can be expressed as:

$$
-k \frac{\left(N W C_{0}\right)}{(1+k)^{1}}-k \frac{\left(N W C_{1}\right)}{(1+k)^{2}}-k \frac{\left(N W C_{2}\right)}{(1+k)^{3}}
$$

If NPV minus EVA is equal to zero, then net working capital will have no influence on the decision metrics. Setting this difference equal to zero yields:

$$
\begin{aligned}
& -N W C_{0}+\left[\frac{N W C_{0}-N W C_{1}+k\left(N W C_{0}\right)}{(1+k)^{1}}\right]+\left[\frac{N W C_{1}-N W C_{2}+k\left(N W C_{1}\right)}{(1+k)^{2}}\right]+\left[\frac{N W C_{2}-N W C_{3}+k\left(N W C_{2}\right)}{(1+k)^{3}}\right]=0 \\
& -N W C_{0}+\left[\frac{\left.N W C_{0}(1+k)-N W C_{1}\right)}{(1+k)^{1}}\right]+\left[\frac{\left.N W C_{1}(1+k)-N W C_{2}\right)}{(1+k)^{2}}\right]+\left[\frac{\left.N W C_{2}(1+k)-N W C_{3}\right)}{(1+k)^{3}}\right]=0 \\
& -N W C_{0}+N W C_{0}-\frac{N W C_{1}}{(1+k)^{1}}+\frac{N W C_{1}}{(1+k)^{1}}-\frac{N W C_{2}}{(1+k)^{2}}+\frac{N W C_{2}}{(1+k)^{2}}-\frac{N W C_{3}}{(1+k)^{3}}=0 \\
& \frac{-N W C_{3}}{(1+k)^{3}}=0
\end{aligned}
$$

Thus, if the firm fully recovers its investment in net working capital $\left(\mathrm{NWC}_{3}=0\right)$, then NPV and EVA will yield identical results. If $\mathrm{NWC}_{3}$ is positive (less than full recovery) then the difference will be negative (NPV-EVA $<0$ ); EVA will be greater than NPV. In such cases it is possible that net working capital differences may cause EVA to accept a project that would be rejected by NPV. 